\title{
An Efficient and Recyclable Nanoparticle-Supported Cobalt Catalyst for Quinoxaline Synthesis
}

\author{
Fatemeh Rajabi ${ }^{1, *}$, Diego Alves ${ }^{2}$ and Rafael Luque ${ }^{3}$
}

Received: 23 September 2015 ; Accepted: 12 November 2015 ; Published: 19 November 2015

Academic Editors: Nicola Cioffi, Antonio Monopoli and Massimo Innocenti

1 Department of Science, Payame Noor University, P. O. Box: 19395-4697, Tehran 19569, Iran

2 Laboratório de Síntese Orgânica Limpa-LASOL, Universidade Federal de Pelotas UFPEL, Pelotas, CEP 96010-900, Brazil; diego.alves@ufpel.edu.br

3 Departamento de Quimica Organica, Universidad de Cordoba, Campus de Rabanales, Edificio Marie Curie (C3), Ctra Nnal IV-A, Km 396, Cordoba E14014, Spain; q62alsor@uco.es

* Correspondence: f_rajabi@pnu.ac.ir; Tel.: +34-957211050 (ext. 1050)

\begin{abstract}
The syntheses of quinoxalines derived from 1,2-diamine and 1,2-dicarbonyl compounds under mild reaction conditions was carried out using a nanoparticle-supported cobalt catalyst. The supported nanocatalyst exhibited excellent activity and stability and it could be reused for at least ten times without any loss of activity. No cobalt contamination could be detected in the products by AAS measurements, pointing to the excellent activity and stability of the Co nanomaterial.
\end{abstract}

Keywords: quinoxaline; catalysis; nanoparticles; cobalt; green chemistry

\section{Introduction}

Quinoxaline derivatives are attractive $N$-containing heterocycles and these scaffolds have attracted much attention, not only in synthetic chemistry [1-3] but also in the medicinal field [4-11]. These compounds exhibit diverse biological activities, such as antiviral [4,5], antibacterial [6], anti-inflammatory [7], antitumoral [8,9] and anti-HIV properties [10,11]. Examples of quinoxalinecontaining pharmacological entities are shown in Figure 1. In addition, quinoxalines have been applied as building blocks for the development of macrocyclic molecular receptors [12,13], semiconducting materials [14-20], dyes [21], cavitands [22] and luminescent materials [23].

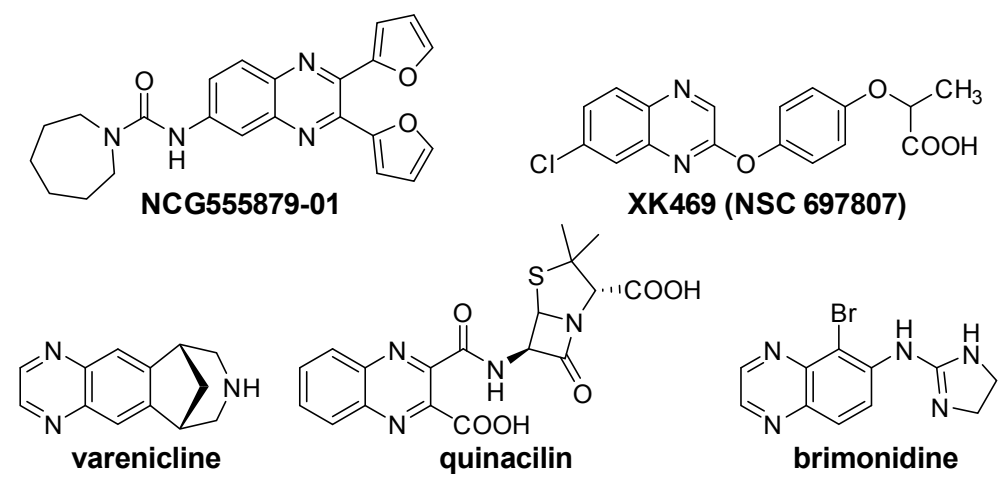

Figure 1. Biologically important quinoxalines.

Generally, quinoxalines can be prepared via a double condensation of 1,2-phenylenediamines with 1,2-diketones [24-28]. A number of reagents have been shown to catalyze these reactions such as acidic alumina [29], citric acid [30], magnetic $\mathrm{Fe}_{3} \mathrm{O}_{4}$ nanoparticles in $\mathrm{H}_{2} \mathrm{O}$ [31], silica-bonded 
sulfonic acid [32], among others [33,34]. Other protocols to synthesize quinoxalines mainly involve the oxidative trapping of vicinal diols or $\alpha$-hydroxy ketones with 1,2-diamines [35-42], 1,4-addition of 1,2-diamines to diazenylbutenes [43], coupling of epoxides with ene-1,2-diamines [44,45], 2-nitroanilines with phenethylamines [46], alkynes or ketones with 1,2-diamines via a key oxidation process [47-51]. Therefore, the development of efficient methods for accessing quinoxalines derivatives continues to be an active area of research.

Nanoparticle-supported catalysts can offer important advantages as compared to homogeneous transition metal systems and colloidal nanoparticles. These include a good reusability coupled with high activities and specificities in different chemistries based on their excelling properties (high surface areas, degenerated density of energy states and plasmon) [52-54]. In this regard, $\mathrm{Co} /$ supported catalysts were previously reported to be highly active and versatile for acid and redox catalyzed processes [54,55].

To the best of our knowledge, there is no protocol describing the preparation of quinoxaline derivatives using a nanoparticle-supported cobalt catalyst. In view of the explained above, we decided to examine the synthesis of substituted quinoxalines by reaction of 1,2-diketones with 1,2-phenylenediamines using a nanoparticle-supported cobalt catalyst (Scheme 1).<smiles>[R]c1ccc(C(=O)C(=O)c2ccc([R])cc2)cc1</smiles>

Scheme 1. General scheme of the reactions.

\section{Results and Discussion}

Initially, we chose 1,2-diphenylethanedione (1a)and 1,2-diamino-4-nitrobenzene (2a) as model substrates to establish the best conditions for this reaction and some experiments were performed to synthesize the corresponding quinoxaline $3 \mathbf{a}$ (Table 1 ). We started our studies reacting 1,2-diketone $\mathbf{1 a}$ $(1.0 \mathrm{mmol})$ with 1,2 -phenylenediamine $2 \mathrm{a}(1.0 \mathrm{mmol})$ at $100^{\circ} \mathrm{C}$ for $2 \mathrm{~h}$, without catalyst and solvent. Under these conditions, product $3 a$ was not obtained (Table 1, entry 1). Good results were obtained however when the reactions of substrates $1 \mathbf{a}$ and $2 \mathbf{a}$ were carried out using $\mathrm{H}_{2} \mathrm{O}$ as solvent in the presence of Co NPs ( $2 \mathrm{~mol} \%$ ) as catalyst. Reactions performed at $100{ }^{\circ} \mathrm{C}$ and $50{ }^{\circ} \mathrm{C}$ gave the desired product in $87 \%$ and $57 \%$ yield, respectively (Table 1, entries 2 and 3). A similar result was obtained when the reaction was conducted at $100{ }^{\circ} \mathrm{C}$, however using $1 \mathrm{~mol} \%$ of Co NPs ( $86 \%$ yield) (Table 1 , entry 4). Good results were also found when the reactions were performed using EtOH as solvent (Table 1, entry 5-9). Excellent yields of product 3a were achieved in reactions carried out in EtOH at $78{ }^{\circ} \mathrm{C}$ using $1 \mathrm{~mol} \%$ of catalyst (Table 1 , entries 7-8). When the amount of catalyst was reduced to $0.5 \mathrm{~mol} \%$, a decrease in the yield of product $3 \mathbf{a}$ was observed (Table 1, entry 9). Finally, the reaction performed using $1 \mathrm{~mol} \%$ of Co NPs at $100{ }^{\circ} \mathrm{C}$ and in absence of EtOH yielded the quinoxaline $3 \mathrm{a}$ in $72 \%$ yield (Table 1 , entry 10 ).

Analyzing the results shown in Table 1, we established the best reaction conditions reacting 1,2-diphenylethanedione (1a, $1.0 \mathrm{mmol}, 0.033 \mathrm{~g}$ ) with 1,2-diamino-4-nitrobenzene (2a, $1.0 \mathrm{mmol})$ using supported CoNPs $(1 \mathrm{~mol} \%)$ as catalyst and $\mathrm{EtOH}(5 \mathrm{~mL})$ as solvent. After that, the mixture was stirred at reflux for $90 \mathrm{~min}$ in open atmosphere, affording 6-nitro-2,3-diphenylquinoxaline(3a) in $92 \%$ yield after crystallization. 
Table 1. Optimization of reaction condition ${ }^{\mathrm{a}}$.

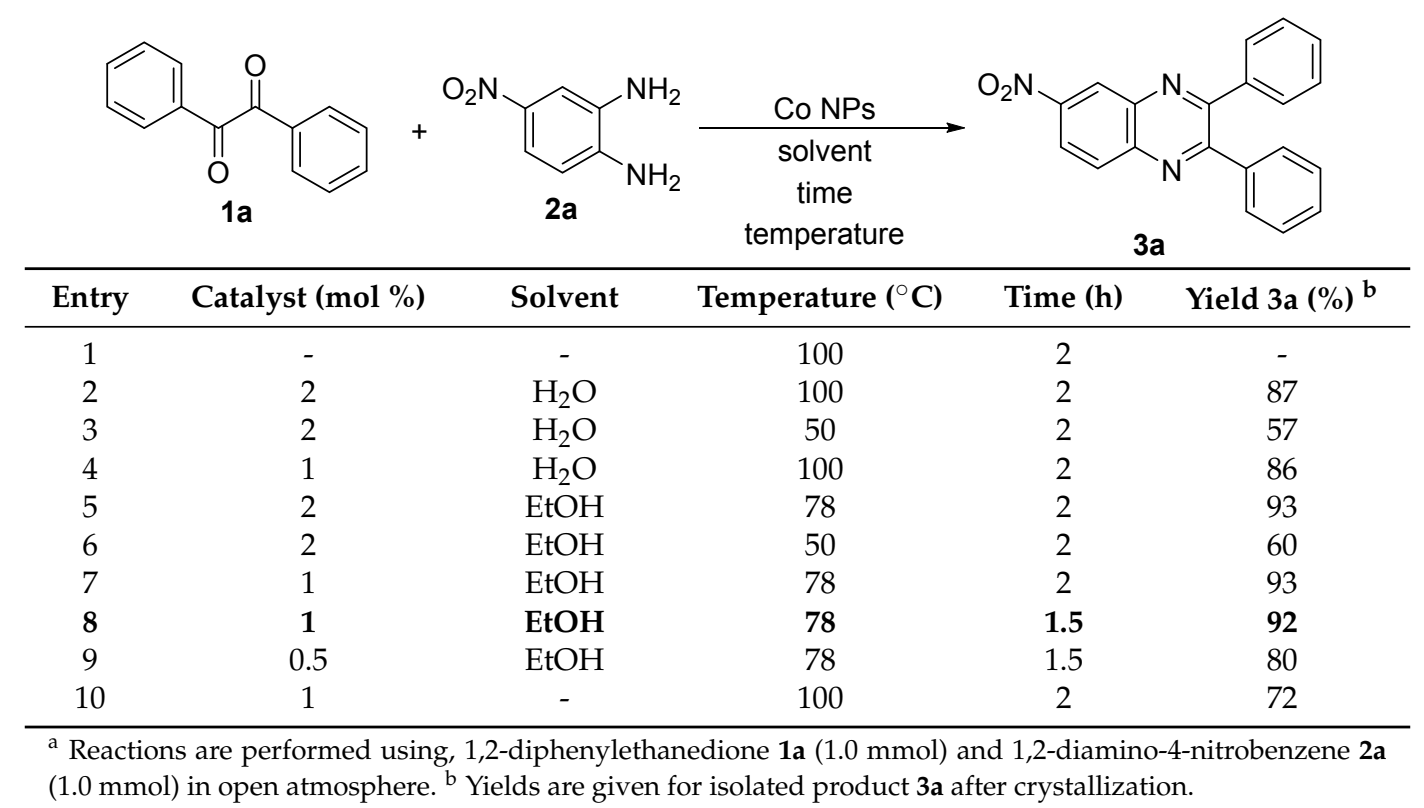

In order to extend the scope of the reaction, the best conditions were employed in reactions of 1,2-diamino-4-nitrobenzene (2a) with other 1,2-diketones $\mathbf{1} \mathbf{b}$-e with different patterns of substitution and the results are summarized in Table 2. As it can be seen on Table 2 (Entries 1-5), our methodology is suitable to a range of substituted 1,2-diketones containing electron-withdrawing groups, affording excellent yields to desired products in all examples. In addition, the possibility of performing the reaction of 1,2-diketones $\mathbf{1 a}$-e with 0 -phenylenediamine (2b) was also investigated (Table 2, entries 6-10). Using these substrates, a range of substituted quinoxalines was obtained in excellent yields using the nanoparticle-supported cobalt catalyst under optimized reaction conditions.

Table 2. Generality of the reaction of 1,2-diketones with 1,2-diamines ${ }^{a}$.

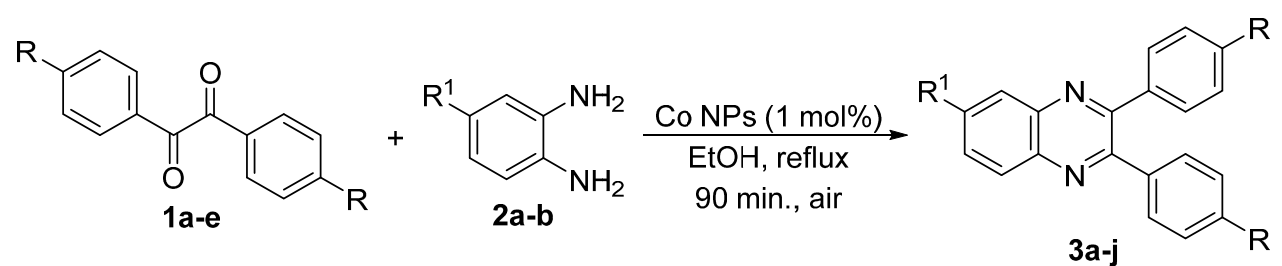

Entry


Table 2. Cont.

\begin{tabular}{|c|c|c|c|c|c|}
\hline Entry & 1,2-Diketone 1 & 1,2-Diamines 2 & Product 3 & Yield $(\%)^{b}$ & M.P. $\left({ }^{\circ} \mathrm{C}\right)$ \\
\hline 3 & 1c & $2 a$ & $3 c$ & 92 & $173-175$ \\
\hline 4 & 1d & $2 a$ & $3 d$ & 90 & 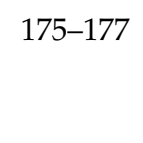 \\
\hline 5 & 1e & $2 a$ & $3 e$ & 88 & $143-145$ \\
\hline 6 & 1a & $2 b$ & $3 f$ & 92 & $127-129$ \\
\hline 7 & $1 b$ & $2 b$ & $3 g$ & 96 & 127-129 \\
\hline 8 & 1c & $2 b$ & $3 h$ & 94 & 133-135 \\
\hline 9 & 1d & $2 b$ & $3 \mathbf{i}$ & 94 & 190-192 \\
\hline 10 & $1 e$ & $2 b$ & $3 \mathbf{j}$ & 94 & 134-135 \\
\hline 11 & & $2 \mathrm{c}$ & $3 k$ & 98 & $116-117$ \\
\hline 12 & & $2 c$ & 31 & 95 & $163-165$ \\
\hline
\end{tabular}

${ }^{a}$ Reactions were performed using 1,2-diketones 1a-e (1.0 mmol), 1,2-diamines 2a-b (1.0 mmol), supported CoNPs $(1 \mathrm{~mol} \%, 0.033 \mathrm{~g})$ and EtOH $(5 \mathrm{~mL})$ at reflux in open flask for $90 \mathrm{~min}$. ${ }^{\mathrm{b}}$ Yields are given for isolated products after crystallization. 
Reused runs were carried out under similarly optimized conditions using $5 \mathrm{mmol}$ 1,2-diphenylethanedione (1a), $5 \mathrm{mmol}$ of 1,2-diamino-4-nitrobenzene (2a) and supported cobalt catalyst $(0.05 \mathrm{mmol}, 0.165 \mathrm{~g})$ at $78^{\circ} \mathrm{C}$ in $10 \mathrm{~mL}$ of ethanol. The catalyst showed excellent recoverability and reusability over ten successive runs under the same conditions as the first run. It is quite remarkable that all materials discussed in this study exhibited outstanding structural stability by TGA (results not shown). The cobalt catalyst was found to be highly stable and reusable under the investigated conditions (up to 12 runs) without any significant loss of its catalytic activity (Table 3). Indeed, ICP analysis of both reaction filtrate and catalyst showed no detectable Co leaching $(<0.5 \mathrm{ppm})$ in the reaction filtrate upon reaction completion, with an almost identical Co content for both fresh and reused catalyst $(0.30$ vs. $0.29 \mathrm{mmol}$ of Co per gram of catalyst for fresh and 10-time reused material, respectively).

Table 3. Reuses of the supported CoNP catalyst in the reaction of 1,2-diphenylethanedione (1a) with 1,2-diamino-4-nitrobenzene (2a).

\begin{tabular}{|c|c|c|c|c|c|c|c|c|c|c|}
\hline Run No. ${ }^{a}$ & 1 & 2 & 3 & 4 & 5 & 6 & 7 & 8 & 9 & 10 \\
\hline Yield $(\%)^{b}$ & 94 & 94 & 92 & 92 & 92 & 90 & 91 & 90 & 90 & 87 \\
\hline
\end{tabular}

The study of the scale-up reaction (from 1 to $20 \mathrm{mmol}$ of substrate) was also investigated under the optimized reaction conditions. When the amount of $\mathbf{1 a}$ and $\mathbf{2 a}$ was increased to $20 \mathrm{mmol}$, the same conversion was obtained after 90 min under optimized conditions.

The catalytic performance of our system was eventually compared to reported literature data. As can be seen in Table 4, our recoverable catalytic system possesses remarkably improved activities as compared to those of related previously reported heterogeneous systems.

Table 4. Comparison of the result in the reaction of 1,2-diphenylethanedione (1a) with 1,2-diaminobenzene (2a) with our method and the previous literature.

\begin{tabular}{ccccc}
\hline Entry & Condition & Time (min) & Yield (\%) & Reference \\
\hline 1 & Polyaniline-sulfate salt $(5 \mathrm{wt} \%), \mathrm{DCE}$, r.t. & 20 & 95 & {$[25]$} \\
2 & $\mathrm{CAN}(5 \mathrm{~mol} \%), \mathrm{H}_{2} \mathrm{O}$, r.t. & 10 & 98 & {$[26]$} \\
3 & $\mathrm{I}_{2}(10 \mathrm{~mol} \%), \mathrm{DMSO}$, r.t. & 35 & 95 & {$[27]$} \\
4 & $\mathrm{MeOH} \mathrm{AcOH}(9: 1), \mathrm{MW}, 160^{\circ} \mathrm{C}$ & 5 & 99 & {$[28]$} \\
5 & Acidic alumina, $80^{\circ} \mathrm{C}$ & 2 & 96 & {$[29]$} \\
6 & $\mathrm{Citric}$ acid $(10 \mathrm{~mol} \%), \mathrm{EtOH}$, r.t. & 1 & 94 & {$[30]$} \\
7 & $\mathrm{Fe}_{3} \mathrm{O}_{4} \mathrm{NPs}(10 \mathrm{~mol} \%), \mathrm{H}_{2} \mathrm{O}$, r.t. & 150 & 95 & {$[31]$} \\
8 & Silicabonded $\mathrm{S}$-sulfonicacid $(3.4 \mathrm{~mol} \%), \mathrm{EtOH} / \mathrm{H}_{2} \mathrm{O}(70 / 30)$, r.t. & 5 & 96 & {$[32]$} \\
9 & $\mathrm{Ga}(\mathrm{OTf})_{3}(1 \mathrm{~mol} \%), \mathrm{EtOH}, \mathrm{rrt.}$ & 5 & 99 & {$[33]$} \\
10 & $\mathrm{Bi}(\mathrm{OTf})_{3}(10 \mathrm{~mol} \%), \mathrm{H}_{2} \mathrm{O}$, r.t. & 5 & 97 & {$[34]$} \\
11 & $\mathrm{CoNP}(1 \mathrm{~mol} \%), \mathrm{EtOH}$, reflux & 90 & 92 & Our work \\
\hline
\end{tabular}

\section{Experimental Section}

\subsection{General Information}

Unless otherwise stated, all reagents and chemicals in this study were used as received and were not further purified (Sigma-Aldrich Chemie $\mathrm{GmbH}$, Taufkirchen, Germany). Melting point recorded on a RY-1 microscopic melting apparatus (Hangzhou Chincan Trading Co., Shanghai, China) and uncorrected. ${ }^{1} \mathrm{H}-\mathrm{NMR}$ and ${ }^{13} \mathrm{C}-\mathrm{NMR}$ spectra were respectively recorded on $500 \mathrm{MHz}$ and 125 $\mathrm{MHz}$ by using a Bruker Avance 500 spectrometer (Bruker BioSpin GmbH, Rheinstetten, Germany). Metal content in the materials was determined using inductively coupled plasma (ICP) in a Philips PU 70000 sequential spectrometer (Philips, Almelo, The Netherlands) equipped with an Echelle monochromator $\left(0.0075 \mathrm{~nm}\right.$ resolution). Samples were digested in $\mathrm{HNO}_{3}$ and subsequently analyzed 
by ICP Nitrogen adsorption measurements (Philips) were carried out at $77 \mathrm{~K}$ using an ASAP 2000 volumetric adsorption analyzer from Micromeritics (Micromeritics, Norcross, GA, USA). The samples were outgassed for $24 \mathrm{~h}$ at $100{ }^{\circ} \mathrm{C}$ under vacuum ( $\mathrm{p} \mathrm{b} 10-2 \mathrm{~Pa}$ ) and subsequently analyzed.

\subsection{Preparation of the Supported Cobalt Catalyst}

CoNPs was synthesized as previously reported [55]. Briefly, salicylaldehyde ( $2 \mathrm{mmol}, 0.244 \mathrm{~g}$ ) was added to an excess of absolute $\mathrm{MeOH}$, to which 3-aminopropyl(trimethoxy)silane ( $2 \mathrm{mmol}$, $0.352 \mathrm{~g}$ ) was subsequently added. The color of the solution instantly changed to yellow indicating imine formation. After $3 \mathrm{~h}$, cobalt (II) acetate, $\mathrm{Co}(\mathrm{OAc})_{2} \cdot 2 \mathrm{H}_{2} \mathrm{O}(1 \mathrm{mmol}, 0.248 \mathrm{~g})$ was added to the solution, and the mixture stirred for three additional hours to allow the new ligands to complex the cobalt. A color change from pink to olive green is observed. SBA-15 (3 g) was activated by refluxing in concentrated hydrochloric acid (6 M) and then washed thoroughly with deionized water and dried before undergoing chemical surface modification. This activation treatment readily hydrolyses the siloxane $\mathrm{Si}-\mathrm{O}-\mathrm{Si}$ bonds to $\mathrm{Si}-\mathrm{OH}$ species which will be key to anchor the cobalt complex. Both complex and activated silica were then mixed and the mixture was stirred overnight. The solvent was removed using a rotary evaporator, and the resulting olive green solid dried at $80^{\circ} \mathrm{C}$ overnight. The final product was washed with $\mathrm{MeOH}$ and water (to remove all physisorbed metal species) until the washings were colourless. Further drying of the solid product was carried out in an oven at $80^{\circ} \mathrm{C}$ for $8 \mathrm{~h}$. The loading of cobalt was calculated about $0.3 \mathrm{mmol} \cdot \mathrm{g}^{-1}$ and surface analysis showed cobalt oxide species well dispersed on the surface of SBA-15 with $450 \mathrm{~m}^{2} \cdot \mathrm{g}^{-1}$ surface area and pore size of $3.6 \mathrm{~nm}$ with $0.77 \mathrm{~cm}^{3} \cdot \mathrm{g}^{-1}$ mesoporous pore volume.

\subsection{General Reaction Procedure}

To a mixture of 1,2-dicarbonyl compound $\mathbf{1 a}-\mathbf{e}(1.0 \mathrm{mmol})$ and 1,2-diamine $\mathbf{2 a - b}(1.0 \mathrm{mmol})$ in ethanol $(5 \mathrm{~mL})$, supported CoNP $(0.033 \mathrm{~g}, 1 \mathrm{~mol} \%)$ was added and the mixture was refluxed in an open flask for $90 \mathrm{~min}$. Reactions were monitored by thin layer chromatography (TLC) until total disappearance of the starting material. After completion of the reaction, the reaction mixture was cooled to room temperature, and resulting solid was collected by filtration and dissolved in ethyl acetate $(10 \mathrm{~mL})$. The supported catalyst was recovered by filtration. After evaporation of solvent, the resulting solid product was purified by crystallization in ethanol.

\subsection{Selected Spectroscopic Data}

6-Nitro-2,3-diphenylquinoxaline (Table 2, Entry 1, 3a). Yellow solid; m.p. $188-190{ }^{\circ} \mathrm{C}$ (lit. [56] 193-194 $\left.{ }^{\circ} \mathrm{C}\right) .{ }^{1} \mathrm{H}-\mathrm{NMR}\left(\mathrm{CDCl}_{3}\right): \delta 7.38(\mathrm{~m}, 6 \mathrm{H}, \mathrm{Ar}-\mathrm{H}), 7.56(\mathrm{~m}, 4 \mathrm{H}, \mathrm{Ar}-\mathrm{H}), 8.28(\mathrm{~m}, 1 \mathrm{H}, \mathrm{Ar}-\mathrm{H}), 8.45$ (m, 1H, Ar-H), $9.02(\mathrm{~m}, 1 \mathrm{H}, \mathrm{Ar}-\mathrm{H}) ;{ }^{13} \mathrm{C}-\mathrm{NMR}\left(\mathrm{CDCl}_{3}\right): \delta 123.27,125.51,128.45,129.67,129.85,129.95$, 130.66, 137.95, 139.87, 143.39, 147.80, 155.62, 156.18.

2,3-Diphenylquinoxaline (Table 2, Entry 6, 3f). White solid; m.p. $127-129{ }^{\circ} \mathrm{C}$ (lit. [26] 126-127 ${ }^{\circ} \mathrm{C}$ ). ${ }^{1} \mathrm{H}-\mathrm{NMR}\left(\mathrm{CDCl}_{3}\right): \delta 7.35(\mathrm{~m}, 6 \mathrm{H}, \mathrm{Ar}-\mathrm{H}), 7.56(\mathrm{~m}, 4 \mathrm{H}, \mathrm{Ar}-\mathrm{H}), 7.76(\mathrm{~m}, 2 \mathrm{H}, \mathrm{Ar}-\mathrm{H}), 8.20(\mathrm{~m}, 2 \mathrm{H}, \mathrm{Ar}-\mathrm{H})$; ${ }^{13} \mathrm{C}-\mathrm{NMR}\left(\mathrm{CDCl}_{3}\right): \delta 128.29,128.89,129.13,129.915,130.10,138.92,141.15,154.38$.

2,3-Bis(4-Fuorophenyl)quinoxaline (Table 2, Entry 8, 3h). White solid; m.p. $133-135{ }^{\circ} \mathrm{C}$ (lit. [56]

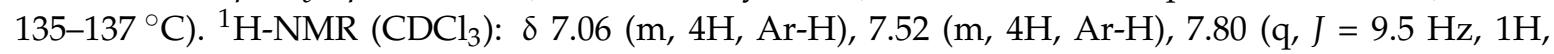
$\mathrm{Ar}-\mathrm{H}), 8.16(\mathrm{q}, J=9.1 \mathrm{~Hz}, 1 \mathrm{H}, \mathrm{Ar}-\mathrm{H}) ;{ }^{13} \mathrm{C}-\mathrm{NMR}\left(\mathrm{CDCl}_{3}\right): \delta 115.45,115.61,129.14,130.22,131.70$, $131.82,134.90,135.02,141.21,152.16,161.54,164.80$.

2,3-Bis(4-Chlorophenyl)quinoxaline (Table 2, Entry 9, 3i).White solid; m.p. 190-192 ${ }^{\circ} \mathrm{C}$ (lit. [32] 195-196 $\left.{ }^{\circ} \mathrm{C}\right) .{ }^{1} \mathrm{H}-\mathrm{NMR}\left(\mathrm{CDCl}_{3}\right): \delta 7.32(\mathrm{~m}, 4 \mathrm{H}, \mathrm{Ar}-\mathrm{H}), 7.49(\mathrm{~m}, 4 \mathrm{H}, \mathrm{Ar}-\mathrm{H}), 7.72(\mathrm{~m}, 2 \mathrm{H}, \mathrm{Ar}-\mathrm{H}), 8.11(\mathrm{~m}$, $2 \mathrm{H}, \mathrm{Ar}-\mathrm{H}) ;{ }^{13} \mathrm{C}-\mathrm{NMR}\left(\mathrm{CDCl}_{3}\right): \delta 128.50,128.62,129.05,129.11,129.17,130.05,130.13,130.26,131.30$, 134.12, 137.36, 138.62, 140.09, 141.11, 153.02, 153.18. 
6-Methyl-2,3-diphenylquinoxaline (Table 2, Entry 11, 3k). Brown solid; m.p. $116-118{ }^{\circ} \mathrm{C}$ (lit. [33] 117-118 $\left.{ }^{\circ} \mathrm{C}\right) .{ }^{1} \mathrm{H}-\mathrm{NMR}\left(\mathrm{CDCl}_{3}\right): \delta 2.61\left(\mathrm{~s}, 3 \mathrm{H}, \mathrm{Ar}-\mathrm{CH}_{3}\right), 7.35(\mathrm{~s}, 6 \mathrm{H}, \mathrm{Ar}-\mathrm{H}), 7.55(\mathrm{~d}, J=6.5,4 \mathrm{H}, \mathrm{Ar}-\mathrm{H})$, $7.60(\mathrm{~s}, 1 \mathrm{H}, \mathrm{Ar}-\mathrm{H}) 7.98(\mathrm{~s}, 1 \mathrm{H}, \mathrm{Ar}-\mathrm{H}), 8.09$ (d, $J=8.4,1 \mathrm{H}, \mathrm{Ar}-\mathrm{H}) ;{ }^{13} \mathrm{C}-\mathrm{NMR}\left(\mathrm{CDCl}_{3}\right): \delta 21.95,128.04$, $128.24,128.67,128.73,129.90,129.92,132.32,139.24,139.73,140.49,141.29,152.55,153.29$.

\section{Conclusions}

In summary, we have developed an environmentally friendly and highly active cobalt nanoparticle on mesoporous SBA-15 material for the synthesis of quinoxalinesin excellent yields from 1,2-diamine and 1,2-dicarbonyl compounds. Reactions could efficiently afford the target products after short reaction times and were run under air and mild reaction conditions and require low loadings of the supported catalyst. The catalyst was found to be highly reusable for at least ten reaction runs under the investigated conditions.

Acknowledgments: F.R. is grateful to Payame Noor University for support of this work.

Author Contributions: F.R. conducted all experimental work, D.A. and R.L. supervised, discussed and completely wrote the manuscript.

Conflicts of Interest: The authors declare no conflict of interest.

\section{References}

1. Brown, D.J. Quinoxalines: Supplement II. In The Chemistry of Heterocyclic Compounds; John Wiley \& Sons: Princeton, NJ, USA, 2004.

2. Katritzky, A.R.; Pozharskii, A.F. Handbook of Heterocyclic Chemistry; Pergamon: Oxford, UK, 2000.

3. Eicher, T.; Hauptmann, S.; Speicher, A. The Chemistry of Heterocycles; Wiley-VCH: Weinheim, Germany, 2003.

4. Moorthy, N.; Hari, N.S.; Manivannan, E.; Karthikeyan, C.; Trivedi, P. $6 H$-Indolo[2,3-b]quinoxalines: DNA and protein interacting scaffold for pharmacological activities. Mini Rev. Med. Chem. 2013, 13, 1415-1420. [CrossRef] [PubMed]

5. Rong, F.; Chow, S.; Yan, S.; Larson, G.; Hong, Z.; Wu, J. Structure-activity relationship (SAR) studies of quinoxalines as novel HCV NS5B RNA-dependent RNA polymerase inhibitors. Bioorg. Med. Chem. Lett. 2007, 17, 1663-1666. [CrossRef] [PubMed]

6. Parhi, A.K.; Zhang, Y.; Saionz, K.W.; Pradhan, P.; Kaul, M.; Trivedi, K.; Pilch, D.S.; LaVoie, E.J. Antibacterial activity of quinoxalines, quinazolines, and 1,5-naphthyridines. Bioorg. Med. Chem. Lett. 2013, 23, 4968-4974. [CrossRef] [PubMed]

7. Smits, R.A.; Lim, H.D.; Hanzer, A.; Zuiderveld, O.P.; Guaita, E.; Adami, M.; Coruzzi, G.; Leurs, R.; Esch, I.J.P. Fragment based design of new $\mathrm{H}_{4}$ receptor-ligands with anti-inflammatory properties in vivo. J. Med. Chem. 2008, 51, 2457-2467. [CrossRef] [PubMed]

8. Hazeldine, S.T.; Polin, L.; Kushner, J.; Paluch, J.; White, K.; Edelstein, M.; Palomino, E.; Corbett, T.H.; Horwitz, J.P. Design, synthesis, and biological evaluation of analogues of the antitumor agent, 2-\{4-[(7-chloro-2-quinoxalinyl)oxy]phenoxy\}propionic acid (XK469). J. Med. Chem. 2001, 44, 1758-1776. [CrossRef] [PubMed]

9. Rajule, R.; Bryant, V.C.; Lopez, H.; Luo, X.; Natarajan, A. Perturbing pro-survival proteins using quinoxaline derivatives: A structure-activity relationship study. Bioorg. Med. Chem. 2012, 20, 2227-2234. [CrossRef] [PubMed]

10. Hui, X.; Desrivot, J.; Bories, C.; Loiseau, P.M.; Franck, X.; Hocquemiller, R.; Figadere, B. Synthesis and antiprotozoal activity of some new synthetic substituted quinoxalines. Bioorg. Med. Chem. Lett. 2006, 16, 815-820. [CrossRef] [PubMed]

11. Kim, Y.B.; Kim, Y.H.; Park, J.Y.; Kim, S.K. Synthesis and biological activity of new quinoxaline antibiotics of echinomycin analogues. Bioorg. Med. Chem. Lett. 2004, 14, 541-544. [CrossRef] [PubMed]

12. Sessler, J.L.; Maeda, H.; Mizuno, T.; Lynch, V.M.; Furuta, H. Quinoxaline-Bridged Porphyrinoids. J. Am. Chem. Soc. 2002, 124, 13474-13479. [CrossRef] [PubMed] 
13. Azov, V.A.; Beeby, A.; Cacciarini, M.; Cheetham, A.G.; Diederich, F.; Frei, M.; Gimzewski, J.K.; Gramlich, V.; Hecht, B.; Jaun, B.; et al. Resorcin[4]arenecavitand-based molecular switches. Adv. Funct. Mater. 2006, 16, 147-156. [CrossRef]

14. Champion, R.D.; Cheng, K.-F.; Pai, C.-L.; Chen, W.-C.; Jenekhe, S.A. Electronic properties and field-effect transistors of thiophene-based donor-acceptor conjugated copolymers. Macromol. Rapid Commun. 2005, 26, 1835-1840. [CrossRef]

15. Wang, E.; Hou, L.; Wang, Z.; Hellström, S.; Zhang, F.; Inganäs, O.; Andersson, M.R. An easily synthesized blue polymer for high-performance polymer solar cells. Adv. Mater. 2010, 22, 5240-5244. [CrossRef] [PubMed]

16. Chang, D.W.; Lee, H.J.; Kim, J.H.; Park, S.Y.; Park, S.-M.; Dai, L.; Baek, J.-B. Novel quinoxaline-based organic sensitizers for dye-sensitized solar cells. Org. Lett. 2011, 13, 3880-3883. [CrossRef] [PubMed]

17. Zhang, X.; Shim, J.W.; Tiwari, S.P.; Zhang, Q.; Norton, J.E.; Wu, P.-T.; Barlow, S.; Jenekhe, S.A.; Kippelen, B.; Brédas, J.-L.; et al. Dithienopyrrole-quinoxaline/pyridopyrazinedonor-acceptorpolymers: Synthesis and electrochemical, optical, charge-transport, and photovoltaic properties. J. Mater. Chem. 2011, 21, 4971-4982. [CrossRef]

18. Zhuang, W.; Zhen, H.; Kroon, R.; Tang, Z.; Hellström, S.; Hou, L.; Wang, E.; Gedefaw, D.; Inganäs, O.; Zhang, F.; et al. Molecular orbital energy level modulation through incorporation of selenium and fluorine into conjugated polymers for organic photovoltaic cells. J. Mater. Chem. A 2013, 1, 13422-13425. [CrossRef]

19. Wang, K.; Zhang, Z.-G.; Fu, Q.; Li, Y. Synthesis and photovoltaic properties of a D-A copolymer based on the 2,3-di(5-hexylthiophen-2-yl)quinoxaline acceptor unit. Macromol. Chem. Phys. 2014, 215, 597-603. [CrossRef]

20. Chen, S.; Zhang, Q.; Zhang, J.; Gu, J.; Zhang, L. Synthesis of two conjugated polymers as TNT chemosensor materials. Sens. Actuators B 2010, 149, 155-160. [CrossRef]

21. Brock, E.D.; Lewis, D.M.; Yousaf, T.I.; Harper, H.H. Reactive Dye Compounds. U.S. Patent WO1999051688 A1, 14 October 1999.

22. Lindner, B.D.; Zhang, Y.; Hoefle, S.; Berger, N.; Teusch, C.; Jesper, M.; Hardcastle, K.I.; Qian, X.; Lemmer, U.; Colsmann, A.; et al. N-fused quinoxalines and benzoquinoxalines as attractive emitters for organic light emitting diodes. J. Mater. Chem. C 2013, 1, 5718-5724. [CrossRef]

23. Thomas, K.R.J.; Velusamy, M.; Lin, J.T.; Chuen, C.-H.; Tao, Y.-T. Chromophore-labeled quinoxaline derivatives as efficient electroluminescent materials. Chem. Mater. 2005, 17, 1860-1866. [CrossRef]

24. Ayaz, M.; Xu, Z.; Hulme, C. Novel succinct routes to quinoxalines and 2-benzimidazolylquinoxalines via the Ugi reaction. Tetrahedron Lett. 2014, 55, 3406-3409. [CrossRef] [PubMed]

25. Srinivas, C.; Kumar, C.N.S.S.P.; Rao, V.J.; Palaniappan, S. Efficient, convenient and reusable polyaniline-sulfate salt catalyst for the synthesis of quinoxaline derivatives. J. Mol. Catal. A Chem. 2007, 265, 227-230. [CrossRef]

26. More, S.V.; Sastry, M.N.V.; Yao, C.-F. Cerium(IV) ammonium nitrate(CAN) as a catalyst in tap water: A simple, proficient and green approach for the synthesis of quinoxalines. Green Chem. 2006, 8, 91-95. [CrossRef]

27. Bhosale, R.S.; Sarda, S.R.; Ardhapure, S.S.; Jadhav, W.N.; Bhusare, S.R.; Pawar, R.P. An efficient protocol for the synthesis of quinoxaline derivatives at room temperature using molecular iodine as the catalyst. Tetrahedron Lett. 2005, 46, 7183-7186. [CrossRef]

28. Zhao, Z.; Wisnoski, D.D.; Wolkenberg, S.E.; Leister, W.H.; Wang, Y.; Lindsley, C.W. General microwave-assisted protocols for the expedient synthesis of quinoxalines and heterocyclic pyrazines. Tetrahedron Lett. 2004, 45, 4873-4876. [CrossRef]

29. Jafarpour, M.; Rezaeifard, A.; Danehchin, M. Easy access to quinoxaline derivatives using alumina as an effective and reusable catalyst under solvent-free conditions. Appl. Catal. A Gen. 2011, 394, 48-51. [CrossRef]

30. Mahesh, R.; Dhar, A.K.; Sasank, T.V.N.V.T.; Thirunavukkarsu, S.; Devadoss, T. Citric acid: An efficient and green catalyst for rapid one pot synthesis of quinoxaline derivatives at room temperature. Chin. Chem. Lett. 2011, 22, 389-392. [CrossRef]

31. Lü, H.-Y.; Yang, S.-H.; Deng, J.; Zhang, Z.-H. Magnetic $\mathrm{Fe}_{3} \mathrm{O}_{4}$ nanoparticles as new, efficient, and reusable catalysts for the synthesis of quinoxalines in water. Aust. J. Chem. 2010, 63, 1290-1296. [CrossRef] 
32. Niknam, K.; Saberi, D.; Mohagheghnejad, M. Silica bonded S-sulfonic acid: A recyclable catalyst for the synthesis of quinoxalines at room temperature. Molecules 2009, 14, 1915-1926. [CrossRef] [PubMed]

33. Cai, J.-J.; Zou, J.-P.; Pan, X.-Q.; Zhang, W. Gallium(III) triflate-catalyzed synthesis of quinoxaline derivatives. Tetrahedron Lett. 2008, 49, 7386-7390. [CrossRef]

34. Yadav, J.S.; Subba Reddy, B.V.; Premlatha, K.; Shankar, K.S. Bismuth(III)-catalyzed rapid synthesis of 2,3-disubstituted quinoxalines in water. Synthesis 2008, 3787-3792. [CrossRef]

35. Hille, T.; Irrgang, T.; Kempe, R. The Synthesis of benzimidazoles and quinoxalines from aromatic diamines and alcohols by iridium-catalyzed acceptorless dehydrogenative alkylation. Chem. Eur. J. 2014, 20, 5569-5572. [CrossRef] [PubMed]

36. Cho, C.S.; Oh, S.G. A new ruthenium-catalyzed approach for quinoxalines from $o$-phenylenediamines and vicinal-diols. Tetrahedron Lett. 2006, 47, 5633-5636. [CrossRef]

37. Jeena, V.; Robinson, R.S. An environmentally friendly, cost effective synthesis of quinoxalines: The influence of microwave reaction conditions. Tetrahedron Lett. 2014, 55, 642-645. [CrossRef]

38. Sithambaram, S.; Ding, Y.; Li, W.; Shen, X.; Gaenzler, F.; Suib, S.L. Manganese octahedral molecular sieves catalyzed tandem process for synthesis of quinoxalines. Green Chem. 2008, 10, 1029-1032. [CrossRef]

39. Robinson, R.S.; Taylor, R.J.K. Quinoxaline synthesis from $\alpha$-hydroxy ketones via a tandem oxidation process using catalysed aerobic oxidation. Synlett 2005, 1003-1005.

40. Kim, S.Y.; Park, K.H.; Chung, Y.K. Manganese(IV) dioxide-catalyzed synthesis of quinoxalines under microwave irradiation. Chem. Commun. 2005, 1321-1323. [CrossRef] [PubMed]

41. Raw, S.A.; Wilfred, C.D.; Taylor, R.J.K. Tandem oxidation processes for the preparation of nitrogen-containing heteroaromatic and heterocyclic compounds. Org. Biomol. Chem. 2004, 2, 788-796. [CrossRef] [PubMed]

42. Aparicio, D.; Attanasi, O.A.; Filippone, P.; Ignacio, R.; Lillini, S.; Mantellini, F.; Palacios, F.; Santos, J.M. Straightforward access to pyrazines, piperazinones, and quinoxalinesby reactions of 1,2-diaza-1,3-butadienes with 1,2-diamines under solution, solvent-free, or solid-phase conditions. J. Org. Chem. 2006, 71, 5897-5905. [CrossRef] [PubMed]

43. Ibrahim, M.M.; Grau, D.; Hampel, F.; Tsogoeva, S.B. $\alpha$-Nitro epoxides in organic synthesis: development of a one-pot organocatalytic strategy for the synthesis of quinoxalines. Eur. J. Org. Chem. 2014, 1401-1405. [CrossRef]

44. Antoniotti, S.; Dunach, E. Direct and catalytic synthesis of quinoxaline derivatives from epoxides and ene-1,2-diamines. Tetrahedron Lett. 2002, 43, 3971-3973. [CrossRef]

45. Nguyen, T.B.; Retailleau, P.; Al-Mourabit, A. A simple and straightforward approach to quinoxalines by iron/sulfur-catalyzed redox condensation of o-nitroanilines and phenethylamines. Org. Lett. 2013, 15, 5238-5241. [CrossRef] [PubMed]

46. Xu, Y.; Wan, X. Ruthenium-catalyzed oxidation of alkynes to 1,2-diketones under room temperature and one-pot synthesis of quinoxalines. Tetrahedron Lett. 2013, 54, 642-645. [CrossRef]

47. Shi, S.; Wang, T.; Yang, W.; Rudolph, M.; Hashmi, A.S.K. Gold-catalyzed synthesis of glyoxals by oxidation of terminal alkynes: one-pot synthesis of quinoxalines. Chem. Eur. J. 2013, 19, 6576-6580. [CrossRef] [PubMed]

48. Okumura, S.; Takeda, Y.; Kiyokawa, K.; Minakata, S. Hypervalent iodine(III)-induced oxidative [4+2] annulation of $o$-phenylenediamines and electron-deficient alkynes: Direct synthesis of quinoxalines from alkyne substrates under metal-free conditions. Chem. Commun. 2013, 49, 9266-9268. [CrossRef] [PubMed]

49. Chen, C.-Y.; Hu, W.-P.; Liu, M.-C.; Yan, P.-C.; Wang, J.-J.; Chung, M.-I. Efficient synthesis of quinoxalines with hypervalent iodine as a catalyst. Tetrahedron 2013, 69, 9735-9741. [CrossRef]

50. Zhang, C.; Xu, Z.; Zhang, L.; Jiao, N. $\mathrm{Et}_{3} \mathrm{~N}$-catalyzed oxidative dehydrogenative coupling of $\alpha$-unsubstituted aldehydes and ketones with aryl diamines leading to quinoxalines using molecular oxygen as oxidant. Tetrahedron 2012, 68, 5258-5262. [CrossRef]

51. Campelo, J.M.; Luna, D.; Luque, R.; Marinas, J.M.; Romero, A.A. Sustainable preparation of supported metal nanoparticles and their applications in catalysis. ChemSusChem 2009, 2, 18-45. [CrossRef] [PubMed]

52. White, R.J.; Luque, R.; Budarin, V.; Clark, J.H.; Macquarrie, D.J. Supported metal nanoparticles on porous materials. Methods and applications. Chem. Soc. Rev. 2009, 38, 481-494. [CrossRef] [PubMed]

53. Astruc, D.; Lu, F.; Aranzaes, J.R. Nanoparticles as recyclable catalysts: The frontier between homogeneous and heterogeneous catalysis. Angew. Chem. Int. Ed. 2005, 44, 7852-7872. [CrossRef] [PubMed] 
54. Rajabi, F.; Feiz, A.; Luque, R. An efficient synthesis of coumarin derivatives using a SBA-15 supported Cobalt(II) nanocatalyst. Catal. Lett. 2015, 145, 1621-1625. [CrossRef]

55. Rajabi, F.; Raessi, M.; Arancon, R.A.D.; Saidi, M.R.; Luque, R. Supported cobalt oxide nanoparticles as efficient catalyst in esterification and amidation reactions. Catal. Commun. 2015, 59, 122-126. [CrossRef]

56. Heravi, M. M.; Taheri, S.; Bakhtiari, K.; Oskooie, H. A. Zn[(L)proline]: A powerful catalyst for the very fast synthesis of quinoxaline derivatives at room temperature. Catal. Commun. 2007, 8, 1341-1344. [CrossRef]

Sample Availability: Samples of the compounds $\mathbf{3 a}-\mathbf{1}$ are available from the authors.

(C) 2015 by the authors; licensee MDPI, Basel, Switzerland. This article is an open access article distributed under the terms and conditions of the Creative Commons by Attribution (CC-BY) license (http:/ / creativecommons.org/licenses/by/4.0/). 